\title{
Acute selenium poisoning by paradise nuts (Lecythis ollaria)
}

\author{
Dieter Müller and Herbert Desel
}

\begin{abstract}
Two previously healthy women developed nausea, vomiting, headache and dizziness for several days, a massive hair loss about 2 weeks later and a discoloration of the fingernails. Detailed diagnostic procedures did not reveal any pathological results. Therapeutic measures did not show any effect. Thallium and arsenic were within normal range in plasma. Delayed quantitative determination of selenium in blood, however revealed toxic values (in case I: $479 \mu \mathrm{g} / \mathrm{L}$ of serum, 8 weeks after ingestion, and in case II $300 \mu \mathrm{g} / \mathrm{L}$ of serum, 9 weeks after ingestion). In retrospect, a relation to the ingestion of paradise nuts could be established.
\end{abstract}

\section{Keywords}

Lecythis ollaria, paradise nuts, selenium, poisoning, plasma and urine, hair loss

\section{Introduction}

Selenium poisoning due to ingestion of natural products has been known for a long time but is rarely observed today. ${ }^{1-4}$ A public discussion on protective effects of selenium ${ }^{5,6}$ against cardiovascular disease ${ }^{7}$ and cancer ${ }^{8,9}$ has led to an increased deliberate consumption of selenium compounds. ${ }^{9,10}$

Since bioavailability of organic selenium compounds is higher and toxicity is lower than that of inorganic selenium compounds, ${ }^{6,11-13}$ plant material is often used as a selenium source for nutritional additives. ${ }^{11-13}$ In the present report, we describe two acute non-intentional human selenium poisonings. Both cases occurred at the same occasion and were caused by ingestion of 'paradise nuts' (Lecythis ollaria).

\section{Case reports}

\section{Case I}

A 46-year-old previously healthy woman developed headache, dizziness, nausea, restlessness, cramps and weakness. Two weeks later, she suffered from increasing hair loss and structural damage of the hair. On week 3, she noticed greyish discoloration lines on all fingernails (Figure 1).

The consulted physicians (specialists in internal medicine, a dermatologist and a gynaecologist) initiated diagnostic procedures. Apart from sonographic signs of a hepatic steatosis and rare supraventricular extrasystoles, the clinical and laboratory investigations, including determination of thyroid stimulating hormone (TSH) and ferritin levels, showed normal results. Testosterone was $1.53 \mu \mathrm{g} / \mathrm{L}$ (normal: $<0.8 \mu \mathrm{g} / \mathrm{L}$ ), 17-beta-estradiol $29.1 \mathrm{ng} / \mathrm{L}$ (normal: $<30 \mathrm{ng} / \mathrm{L}$ ), and sex hormone binding globuline (SHBG) $214 \mathrm{nmol} / \mathrm{L}$ (normal range: $30-95 \mathrm{nmol} / \mathrm{L}$ ). A trichogram indicated alopecia diffusa (early type) with dystrophic follicles. The dermatologist performed a supportive intravenous course of therapy with panthenol (Bepanthen ${ }^{\mathrm{R}}$ ), $10 \times$ $500 \mathrm{mg}$, and external therapy with minoxidil, $2 \%$ in 2-propanol, against hair loss. The internist prescribed an oral iron supplementation and the gynaecologist, assuming an endocrine cause because of elevated testosterone and SHBG levels, initiated antiandrogen therapy with cyproterone acetate, $2 \mathrm{mg}$, and ethinylestradiol, $0.035 \mathrm{mg}$ per day. However, all therapeutic measures showed no effect. Cranial magnetic resonance imaging, performed because of the patient's headache, revealed no pathological findings; in

GIZ - Nord Poisons Centre, Universitätsmedizin Göttingen, Georg-August-Universität, Göttingen, Germany

\section{Corresponding author:}

Dieter Müller, GIZ - Nord Poisons Centre, Universitätsmedizin Göttingen, Georg-August-Universität, Robert-Koch-Str. 40, 37075 Göttingen, Germany.

E-mail: dmueller@med.uni-goettingen.de 


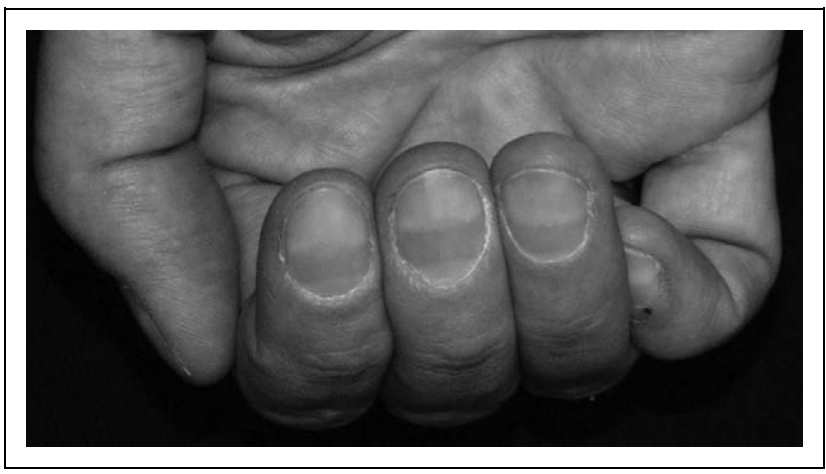

Figure I. Greyish discoloration of all fingernails (case I).

particular, regular imaging of the pituitary gland was observed.

On week 6 , the patient discovered that another woman working in the same office suffered from similar symptoms, occurring at a comparable time course (see case II).

Careful investigation revealed that both had ingested a 'handful' of selenium-rich 'paradise nuts' (Lecythis ollaria) when the office staff had visited an oil mill the day the early symptoms had appeared. None of the other visitors had tasted the nuts and thus none of the other staff members had developed symptoms. Since paradise nuts may contain high selenium, a causative relationship was suspected on week 8 . The plasma level of selenium was then determined to be $479 \mu \mathrm{g} / \mathrm{L}$ (reference level ${ }^{14}: 74-139 \mu \mathrm{g} / \mathrm{L}$, graphite furnace atomic absorption spectrometry method as described in ${ }^{15}$ using GF-AAS Solaar M6 Device, Thermo Fisher Scientific, Dreieich, Germany). On week 14, it was found to have decreased to $246 \mu \mathrm{g} /$ L. A serum concentration of about $1000 \mu \mathrm{g} / \mathrm{L}$ during the symptoms can be extrapolated for the early days after exposure (Figure 2). Thallium and arsenic were determined to be within a normal range in plasma.

No specific therapy was performed. After 12 months, all symptoms had decreased. The selenium level in serum was $152 \mu \mathrm{g} / \mathrm{L}$ (reference level ${ }^{14}: 74-139 \mu \mathrm{g} / \mathrm{L}$ ), the selenium urine concentration $25.2 \mu \mathrm{g} / \mathrm{L}$ (normal range: $2-31 \mu \mathrm{g} / \mathrm{L}$ ), and the selenium excretion in urine $49.1 \mu \mathrm{g} / 24$ hours.

\section{Case II}

A 38-year-old previously healthy woman developed nausea, vomiting and dizziness. About 12 days later, she developed substantial hair loss and itching skin lesions on the scalp. During the third week, she noticed greyish discoloration of all fingernails.

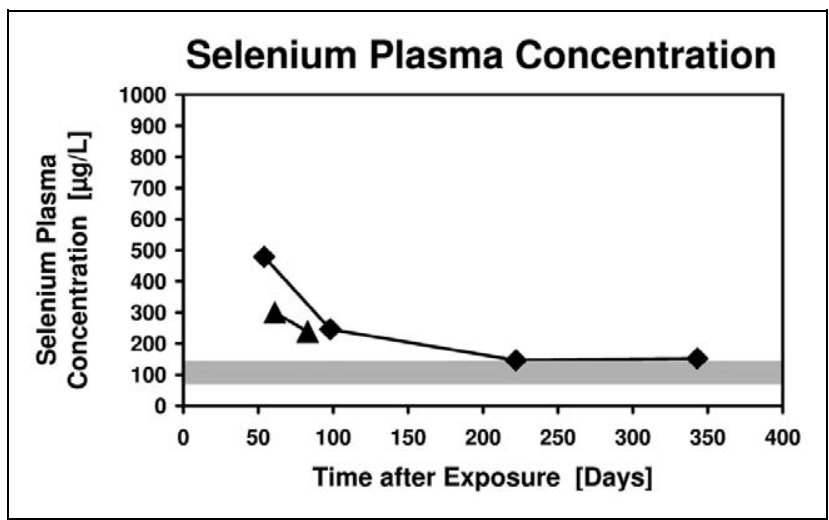

Figure 2. Changes in plasma selenium concentration during I-year post exposure (case I: square, case II: triangular. method of selenium determination: graphite furnace atomic absorption spectrometry, ${ }^{15}$ reference level $^{14}$ : 74-139 $\mu \mathrm{g} / \mathrm{L}$ [grey bar]).

Another consulted physician initiated a laboratory investigation that showed normal results, except for cholesterol $(234 \mathrm{mg} / \mathrm{dL}$, normal $<200 \mathrm{mg} / \mathrm{dL})$ and testosterone $(0.1 \mu \mathrm{g} / \mathrm{L}$, normal range: $0.2-0.8 \mu \mathrm{g} / \mathrm{L})$. Dehydroepiandrosterone was $1447 \mu \mathrm{g} / \mathrm{L}$ (normal range: $450-2700 \mu \mathrm{g} / \mathrm{L}$ ). Histopathological examination of the scalp revealed a decreased number of hair follicles without signs of inflammation and without typical changes for lupus erythematodes. Alopecia areata and androgenetic alopecia were discussed. External therapy with steroids did not show any effect. A wig became necessary. The patient suffered from psychological problems concerning hair loss.

On week 6 , she met the woman described in case I, and selenium was determined in plasma at $300 \mu \mathrm{g} / \mathrm{L}$ (the same laboratory, reference level ${ }^{14}: 74-139 \mu \mathrm{g} / \mathrm{L}$ ) about 2 months post exposure, and at $238 \mu \mathrm{g} / \mathrm{L}$ about 3 weeks later (Figure 2). No specific therapy was performed.

\section{Discussion}

Selenium is an essential trace element that fulfils important functions, for example as a co-factor of glutathione peroxidase, which is necessary in coping with oxidative stress. ${ }^{16-18}$ The discussion regarding protective effects ${ }^{6}$ against myocardial changes, ${ }^{5}$ cardiovascular disease ${ }^{7}$ and cancer $^{8}$ has led to an increased consumption of dietary supplements containing selenium in different organic and inorganic compounds. $^{4,10}$ Since bioavailability and reactivity of organic selenium compounds is higher and toxicity 
is lower than that of inorganic selenium, $6,8,11,12,19,20$ plant products are frequently used as a selenium source for nutritional additives. Especially nutritional additives containing paradise nuts are available in internet shops.

The proposed daily intake has been defined for selenium compounds by several regulating guidelines. Values have been reduced to $55 \mu \mathrm{g} /$ day recently (recommended dietary allowances). ${ }^{21}$ Epidemiologic studies have shown that average human selenium intake and body-burden roughly correspond to the selenium content of local soil, which varies within a wide range in different regions. ${ }^{22}$ Inhabitants in regions with very low selenium content (daily intake $10 \mu \mathrm{g} / \mathrm{d}$ ) suffer from selenium deficiency: 'Keshan-disease,' a form of cardiomyopathy in combination with a serum selenium level of $20 \mu \mathrm{g} / \mathrm{L}$, and 'Kashin-Beck-Syndrome, ${ }^{23}$ a dystrophic osteoarthrosis and spondylarthrosis, have been described in China. Chinese regions by historical outbreaks of human selenosis have been reported as being at risk of chronic selenium intoxications (averaged selenium blood levels: $3200 \mu \mathrm{g} / \mathrm{L}){ }^{1}$ Also, cattle consuming plants able to accumulate organic selenium may be intoxicated. Changes of the hair, loss of hair and nails, 'hoof-rot' and several neurologic symptoms including amaurosis and ataxia ('blind staggers') have been described to occur. $^{2}$ Traditionally, the toxicity of seleniumcontaining plants is well known to native populations. Acute intoxications usually happen to visitors who are not aware of the toxicity of the selenium-rich fruits, like the two women in the reported cases who consumed nuts corresponding to Lecythis ollaria. ${ }^{3}$

Nuts of Lecythis ollaria contain substantial amounts of seleno-cystathionine (7-12 g selenium/kg dry mass) ${ }^{24}$ when growing on selenium-rich grounds in South America. ${ }^{2,3}$ Several selenium poisonings after ingestion of seven or more of these nuts have been documented in the literature. ${ }^{3}$ The symptoms after ingestion of a comparable amount of nuts described 40 years ago are identical to the symptoms of the two patients described here who may have had a plasma selenium level of more than $1000 \mu \mathrm{g} / \mathrm{L}$ in the early days after exposure. A sample of the nuts ingested in these cases was not available.

There are few human data concerning acute intoxications with organic selenium compounds dealing with time course of plasma concentration and symptoms of toxicity.

Most of the reports describe intoxications after ingestion of inorganic selenium compounds.
Clark reported comparable symptoms after 2 weeks of a daily intake of vitamin tablets accidentally containing $2.5-5 \mathrm{mg}$ instead of declared $5 \mu \mathrm{g} / \mathrm{tablet}$ of (anorganic) selenium causing a selenium plasma level of $652 \mu \mathrm{g} / \mathrm{L}$ (reference level: $55-130 \mu \mathrm{g} / \mathrm{L}$ ). Two weeks later, plasma selenium was determined to be in a normal range. ${ }^{4}$

Gasmi reviewed acute poisonings with anorganic selenium compounds as the most frequent reason for acute selenium poisonings. He concluded that maximum selenium plasma concentrations of less than $1000 \mu \mathrm{g} / \mathrm{L}$ are predictive of no severe damage, and levels above $2000 \mu \mathrm{g} / \mathrm{L}$ are predictive of serious complications. These results correspond with the extrapolated selenium plasma level of case I of more than $1000 \mu \mathrm{g} /$ $\mathrm{L}$ with lasting gastrointestinal symptoms and massive hair loss. ${ }^{25}$ The slow decrease of plasma selenium after a singular ingestion of paradise nuts corresponds with former studies with 75-selenium compounds that showed longer terminal half-life of organic compared with anorganic selenium compounds. ${ }^{26}$

Nuttall compared intoxications with anorganic selenium compounds by means of selenium serum levels and discriminated between 3 categories: Blood selenium levels associated with acute toxicity ranged between 400 and $30.000 \mu \mathrm{g} / \mathrm{L}$, with chronic toxicity between 500 and $1400 \mu \mathrm{g} / \mathrm{L}$ and free of toxicity with less than $1400 \mu \mathrm{g} / \mathrm{L}$ (reports from seleniferous regions in china).

Fatalities that occurred within the first day after ingestion of anorganic selenium compounds were associated with postmortem selenium concentrations above $1400 \mu \mathrm{g} / \mathrm{L}{ }^{19}$

$\mathrm{See}^{27}$ reports a poisoning following the ingestion of sodium selenite, which was taken as a therapeutic attempt against a suspected prostate cancer according to an information from the internet. The dose of $10 \mathrm{~g}$ led to death after 6 hours. Four hours after ingestion the serum level was determined to be $5354 \mu \mathrm{g} / \mathrm{L}$. Recently Schrauzer reviewed the historical development of selenium in human and animal nutrition. ${ }^{28}$

\section{Conclusion}

An increasing market of selenium-containing dietary supplements includes products of biological origin. Selenium poisonings caused by Lecythis ollaria or other selenium-accumulating plants may become more prevalent. Beside the toxicologically relevant heavy metals or metalloids like thallium and arsenic, selenium should be included in our diagnostic considerations in such cases of hair loss and nail discoloration. 


\section{References}

1. Yang G, Wang S, Zhou R, Sun S. Endemic selenium intoxication of humans in china. Am J Clin Nutr 1983; 37: 872-881.

2. Kerdel-Vegas F, Wagner F, Russell PB, et al. Structure of the pharmacologically active factor in the seeds of Lecythis ollaria. Nature 1965; 205: 1186-1187.

3. Kerdel-Vegas F. The depilatory and cytotoxic action of "Coco De Mono" (Lecythis ollaria) and its relationship to chronic seleniosis. Economic Bot 1966; 20: 187-195.

4. Clark RF. Selenium poisoning from a nutritional supplement. JAMA 1996; 275: 1087-1088.

5. Manati W, Vaillant F, Bost M, et al. Protective role of selenium supplementation against cardiac lesions induced by the combination of levomepromazine and risperidone in the rabbit. Hum Exp Toxicol 2009; 28: 461-467.

6. Nordberg GF (ed.). Handbook on the toxicology of metals. 3rd ed. Elsevier: Amsterdam, 2007, p.783-807.

7. Salonen IT, Alfthan G, Huttunen IK, Pikkaramen J, Puska P. Association between cardiovascular death and myocardial infarction and serum selenium in a matched-pair longitudinal study. Lancet 1982; 2: 175-179.

8. Ip C. The chemoprotective role of selenium in carcinogenesis. J Am Coll Toxicol 1986; 5: 7-20.

9. Dennis T, Fanous M, Mousaa S. Natural products for chemopreventive and adjunctive therapy in oncologic disease. Nutr Cancer 2009; 61: 587-597.

10. Dietary reference intakes for vitamin C, vitamin E, selenium, and carotinoids. Institute of medicine, Washington, DC. National Academies press, p.310-311, http://www.nap.edu/openbook.php?isbn= 0309069351\& page $=310 \quad$ (2000, accessed October 2009).

11. McAdam PA. Chronic toxicity and retention of dietary selenium fed to rats and D- or L-selenomethionine, selenite or selenate. Nutr Res 1987; 7: 601-610.

12. Sayato Y. Acute and subacute oral toxicity of selenocystine in mice. Jpn J Toxicol Environ Health 1993; 39: 289-296.

13. Taylor D, Dalton C, Hall A, et al. Recent developments in selenium research. Br Biomed Sci 2009; 66: 107-116.

14. Thomas L (ed.). Labor und Diagnose - Indikation und Bewertung von Laborbefunden für die medizinische Diagnostik. 7th ed. TH-Books-Verl.-Ges.: Frankfurt/ Main 2008, p.498-501.

15. Lin TH, Tseng WC, Cheng SY. Direct determination of selenium in human blood plasma by graphite furnace atomic absorptionsspectrophotometry and clinical application. Biol Trace Elem Res 1998; 64: 133-149.

16. Barceloux DG. Selenium. J Toxicol Clin Toxicol 1999; 37: $145-172$.

17. Rotruck JT, Pope AL, Ganther HE. Selenium: biochemical role as a component of glutathione peroxidase. Science 1972; 179: 588-590.

18. Tapiero H, Townsend DM, Tew KD. The antioxidant role of selenium and seleno-compounds. Biomed Pharmacother 2003; 57: 134-144.

19. Nuttall KL. Evaluating selenium poisoning. Ann Clin Lab Sci 2006; 36: 409-420.

20. Levander OA, Alfthan G, Arvilommi H, et al. Bioavailability of selenium to finnish men as assessed by platelet glutathione peroxidase activity and other blood parameters. Am J Clin Nutr 1983; 37: 887-897.

21. Toxicological Profile for Selenium, Agency for Toxic Substances and Disease Registry (ATSDR), September 2003. http://www.atsdr.cdc.gov/toxprofiles/tp92.html (accessed October 2009).

22. Alfthan G, Neve J. Reference values from serum selenium in various areas - evaluated according to the TRACY protocol. J Trace Elements Med Biol 1996; 10: 77-87.

23. Hou S, Zhu Z, Tan J. The relationship between the selenium dynamics in the course of human body growth and the Kashin-Beck disease epidemiology. Acta Geogr Sinica 1984; 39: 75-85.

24. Hammel C, Kyriakopoulos A, Behne D, et al. Proteinbound selenium in the seeds of coco de mono (Lecythis ollaria). J Trace Elem Med Biol 1996; 10: 96-102.

25. Gasmi A, Garnier R, Gaudillat C, et al. Acute selenium poisoning. Vet Hum Toxicol 1997; 39: 304-308.

26. Bopp BA, Sonders RC, Kesterton JW. Metabolic fate of selected selenium compounds in laboratory animals and man. Drug Metabol Rev. 1982; 13: 271-318.

27. See K, Lavercombe PS, Dillon J, Ginsberg R. Accidental death from acute selenium poisoning. Med J Aust 2006; 185: 388-389.

28. Schrauzer GN, Surai PF. Selenium in human and animal nutrition: resolved and unresolved issues. A partly historical treatise in commemoration of the fiftieth anniversary of the discovery of the biological essentiality of selenium, dedicated to the memory of Klaus Schwarz (1914-1978) on the occasion of the thirtieth anniversary of his death. Crit Rev Biotechnol 2009; 29(1):2-9. 